\title{
Human Security and International Law: The Potential Scope for Legal Development within the Analytical Framework of Security
}

\author{
Hitoshi Nasu*
}

\begin{abstract}
Human security is a human or people-centred and multi-sectoral approach to security, emphasising the empowerment of people to enhance their potential through concerted efforts to develop norms, processes and institutions that systematically address insecurities. Although the idea itself arguably precedes the formation of the Westphalian system, it was the UN Development Programme that captured it into policy discourse in 1994. Since then, the idea has facilitated, for example, the adoption of new treaties concerning the protection of civilians during and in the aftermath of armed violence, and has informed debates as to how certain rules of international law should be interpreted or applied. After locating human security within the analytical framework of security, this paper considers legal or structural obstacles to the notion of human security being harnessed more widely across all fields of international law. This chapter finds that the notion of human security challenges international law not only in respect of its sovereignty-based legal framework but more significantly in relation to the very notion of security shared by policymakers and jurists in legal contexts.
\end{abstract}

\section{Introduction}

Human security is a human or people-centred and multi-sectoral approach to security, which means the protection of people from critical and pervasive threats and situations, and the empowerment of people to develop their potential, through concerted efforts to develop norms, processes and institutions that systematically address insecurities. ${ }^{1}$ Even though the idea of human security, at its core, arguably precedes the formation of the Westphalian system, ${ }^{2}$ it was the UN Development Programme (UNDP) that captured it into policy discourse in its 1994 Human

\footnotetext{
* This research was partly supported under the Australian Research Council's Discovery Project funding scheme (Project Number: DP130103683). I thank Shiang Ye for her research assistance at the final stage of the preparation of this manuscript.

${ }^{1}$ Commission on Human Security, 'Human Security Now' (2003) <http://www.humansecuritychs.org/finalreport/index.html> accessed 25 June 2011. See generally, David Chandler and Nik Hynek (eds), Critical Perspectives on Human Security: Rethinking Emancipation and Power in International Relations (Routledge, 2011); Moufida Goucha and John Crowley (eds), Rethinking Human Security (Wiley-Blackwell \& UNESCO, 2008); Shahrbanou Tadjbakhsh and Anuradha M Chenoy, Human Security: Concepts and Implications (Routledge, 2007); Mary Kaldor, Human Security: Reflections on Globalization and Intervention (Polity, 2007); Georg Frerks and Berma Klein Goldewijk (eds), Human Security and International Security (Wageningen Academic Publishers, 2007); S Neil MacFarlane and Yuen Foong Khong, Human Security and the UN: A Critical History (Bloomington: Indiana University Press, 2006); Majid Tehranian (ed), Worlds Apart: Human Security and Global Governance (I B Tauris, 1999).

${ }^{2}$ Emma Rothschild, 'What is Security?' (1995) 124(3) Daedalus 53, 60-65.
} 
Development Report. ${ }^{3}$ Human security has since then been incorporated into key UN policy documents such as the 2000 UN Millennium Declaration, ${ }^{4}$ the 2004 Report of the UN Secretary-General's High-Level Panel, ${ }^{5}$ the 2005 In Larger Freedom Report, ${ }^{6}$ and the UN Secretary-General's Report on Human Security in 2010 and 2012. ${ }^{7}$ World leaders affirmed in the 2005 World Summit Outcome the notion of human security as encompassing 'the right of people to live in freedom and dignity, free from poverty and despair', ${ }^{8}$ and since then have continued to debate the notion of human security in the UN General Assembly. ${ }^{9}$

The policy debate concerning security has consequently moved beyond traditional state-centric security paradigms. ${ }^{10}$ There is no doubt that the notion of human security has paved the way for a shift in focus, away from the domain of national security and towards a broader spectrum, which assists us in defining new security concerns or redefining the terms of the debate surrounding traditional security threats. ${ }^{11}$ Within the field of international law the idea has facilitated, for example, the adoption of new treaties concerning the protection of civilians during and in the aftermath of armed violence and has also informed debates as to how certain rules of international law should be interpreted or applied. Yet, the actual impacts of human security for the development of international law have so far been limited to a few specific areas such as arms control, forced displacement and humanitarian intervention.

This chapter considers legal or structural obstacles to the notion of human security being harnessed more widely across all fields of international law. It does not intend to provide a comprehensive analysis of how the idea of human security has influenced the development of international law, as earlier studies have already examined this matter in many different respects. ${ }^{12}$ Rather, this chapter examines the potential of

\footnotetext{
${ }^{3}$ UN Development Programme (UNDP), Human Development Report 1994 (United Nations 1994) 22.

${ }^{4}$ UNGA Res 55/2 (8 September 2000) UN Doc A/RES/55/2.

${ }^{5}$ Secretary-General's High-Level Panel on Threats, Challenges and Change, 'A More Secure World: Our Shared Responsibility' (2004) UN Doc A/59/565, 23 (identifying economic and social threats, transnational organised crime, as well as inter-state conflict, internal conflict, terrorism, and weapons of mass destruction as global security threats).

${ }^{6}$ Kofi A Annan, In Larger Freedom: Towards Development, Security and Human Rights for All (United Nations 2005) para.78 (listing poverty, deadly infectious disease, and environmental degradation as global security threats on the grounds that these can have equally catastrophic consequences).

7 Report of the Secretary-General, 'Human Security' (2010) UN Doc A/64/701; Report of the Secretary-General, 'Follow-up to General Assembly Resolution 64/291 on Human Security' (2012) UN Doc A/66/763.

82005 World Summit Outcome, UNGA Res 60/1 (24 October 2005) UN Doc A/RES/60/1, para.143.

${ }^{9}$ UN Doc A/66/PV.112 (4 June 2012); UN Doc A/64/PV.88 (20 May 2010); UNGA Thematic Debate on Human $\quad$ Security (22 2008$)$ <http://www.un.org/ga/president/62/ThematicDebates/humansecurity.shtml> accessed 7 April 2012.

${ }^{10}$ For different security paradigms in political science, see, eg, Paul Battersby and Joseph M Siracusa, Globalization and Human Security (Rowman \& Littlefield Publishers 2009) 39-68.

${ }^{11}$ Karen O'Brien, 'Are We Missing the Point? Global Environmental Change as an Issue of Human Security' (2006) 16 Global Environmental Change 2.

${ }^{12}$ See, eg, Hitoshi Nasu, 'The Place of Human Security in Collective Security' (2013) 18 Journal of Conflict \& Security Law 95-129; Tom Farer, 'Human Security: Defining the Elephant and Imagining Its Tasks' (2010) 1 Asian Journal of International Law 1; Alice Edwards and Carla Ferstman (eds), Human Security and Non-Citizens: Law, Policy and International Affairs (Cambridge University Press, 2010); Barbara von Tigerstrom, Human Security and International Law: Prospects and Problems (Hart Publishing 2007); Ben Saul, 'The Dangers of the United Nations' "New Security Agenda": "Human Security” in the Asia-Pacific Region' (2006) 1 Asian Journal of Comparative Law Article 10; Matthias
} 
human security in the areas where it has not influenced the development of international law. To that end, after locating the notion of human security within the analytical framework of security in general (Section 2), this chapter examines the extent to which the notion of human security has or has not informed the development of international law in each of three different dimensions comprising the analytical framework of security, namely: (1) the focus (referent object) of security; (2) the scope of security issues; and (3) the means by which security threats are addressed.

\section{Locating Human Security within the Analytical Framework of Security}

When the world leaders agreed upon adopting the notion of human security in the 2005 World Summit Outcome, the definitional issue was expressly left for subsequent discussion. ${ }^{13}$ Subsequently, UN member states discussed human security in the General Assembly on 22 May 2008, in which different perspectives were presented and weighed the potential benefits of broadening human security against the risks it might pose. While some states highlighted the risk of draining human security of any real operational value and applicability, other states underlined the risk of limiting the concept too narrowly, referring to the benefit of improving the living conditions of those most in need. ${ }^{14}$

Following the thematic debate, the UN Secretary-General Ban Ki-Moon was tasked with seeking the views of UN member states on the notion and definition of human security. ${ }^{15}$ In his 2012 report, however, the Secretary-General chose to set out the core values, scope, approach and common understanding of human security, rather than define it with specific and clear terms. ${ }^{16}$ While some states have lamented the lack of a clear definition, ${ }^{17}$ this approach appears overall to have been well received. ${ }^{18}$ Switzerland, in particular, supported the approach arguing that a precise scientific or legal definition 'would ultimately limit its intrinsic usefulness' ${ }^{19}$

The definitional debate of human security comes down to how we understand 'security' as much as what we mean by 'human'. Security is an elastic and dynamic concept susceptible to change resulting from both objective conditions and the subjective perception of threats. ${ }^{20}$ It is often described as 'an essentially contested

C Kettemann, 'The Conceptual Debate on Human Security and Its Relevance for the Development of International Law' (2006) 1(3) Human Security Perspectives 39; Gerd Oberleitner, 'Human Security: A Challenge to International Law?' (2005) 11 Global Governance 185; Nicholas Thomas and William T Tow, 'The Utility of Human Security: Sovereignty and Humanitarian Intervention' (2002) 33(2) Security Dialogue 177; Rob McRae and Don Hubert (eds), Human Security and the New Diplomacy: Protecting People, Promoting Peace (McGill-Queen's University Press 2001).

${ }^{13}$ UNGA Res 60/1 (24 October 2005) UN Doc A/RES/60/1, para.143.

14 See, UNGA Thematic Debate on Human Security (22 May 2008) <http://www.un.org/ga/president/62/ThematicDebates/humansecurity.shtml > accessed 7 April 2012.

${ }^{15}$ UNGA Res 64/291 (27 July 2010) UN Doc A/RES/64/291, para.3.

${ }^{16}$ Report of the Secretary-General (2012) (n 7).

${ }^{17}$ UN Doc A/66/PV.112 (4 June 2012) 6-7 (Cuba), 8 (Venezuela), 11-12 (Russia), 17 (Malaysia), 21 (China).

${ }^{18}$ Ibid, 3 (European Union), 4 (Jordan on behalf of the Human Security Network), 7 (Mexico), 9 (Japan), 10 (Australia), 11 (Switzerland), 14 (Costa Rica), 14-15 (India), 16 (Thailand).

${ }^{19}$ UN Doc A/66/PV.112 (4 June 2012) 11.

${ }^{20}$ Arnold Wolfers, “National Security” as an Ambiguous Symbol' (1952) 67(4) Political Science Quarterly 481-502, at 484-485. 
concept', ${ }^{21}$ due to the fact that it can be understood differently; depending on its objects, the perception of threats, the protected values, and the means through which these values can be protected. ${ }^{22}$ Likewise, human security is not a coherent or objective concept that can be defined with a definite and precise meaning, but rather forms part of an evolving conception of security that reflects the impacts of different values and norms on international relations. ${ }^{23}$ There can be no single meaning or definition of human security. Indeed, different states, policy makers and scholars have envisaged different ranges of human security issues. ${ }^{24}$ Nevertheless, the analytical framework of security in general can provide a conceptual way of understanding the debates concerning the current state and role of human security in the development of international law. ${ }^{25}$

In the discourse of security studies, human security is, first and foremost, understood as a shift in 'referent objects' of security from sovereign states or the international community to human beings. ${ }^{26}$ Ambiguity remains as to whether it is particular individual persons or human beings as a collective mass that constitute the referent object in the discourse of human security. Peter Hough, for example, understands human security as the 'deepening' of security, placing individual persons at the centre of security analysis and policy-making. ${ }^{27}$ Barry Buzan, on the other hand, warns against the 'reductionism' caused by human security in international security thinking, emphasising the collectivity of security enterprises as an essential element of referent objects. ${ }^{28}$ This issue informs the debate, as will be discussed below, regarding the extent to which human security overlaps with or distinguishes itself from human rights.

Second, not only does human security shift the focus of referent objects to human beings, it also entails a broadened, multi-sectoral understanding of security and

\footnotetext{
${ }^{21}$ Barry Buzan, People, States and Fear: The National Security Problems in International Relations (Brighton: Wheatsheaf, 1983) 6.

${ }^{22}$ See generally, David A Baldwin, 'The Concept of Security' (1997) 23 Review of International Studies 5-26.

${ }^{23}$ Edward Newman, 'Human Security and Constructivism' (2001) 2 International Studies Perspectives 239.

${ }^{24}$ See, eg, Amitav Acharya, 'Human Security: East versus West' (2001) 56 International Journal 442460 .

${ }^{25}$ For the author's earlier work on the analytical framework of security in the context of international law, see, Hitoshi Nasu, 'Law and Policy for Antarctic Security: An Analytical Framework' in Alan D Hemmings, Donald R Rothwell and Karen N Scott (eds), Antarctic Security in the Twenty-First Century: Legal and Policy Perspectives (Routledge, 2012) 18-32; Hitoshi Nasu, 'The Expanded Conception of Security and International Law: Challenges to the UN Collective Security System' (2011) 3(3) Amsterdam Law Forum 15-33. See also, Tadjbakhsh and Chenoy, (n 1) 13-19.

${ }^{26}$ According to the 'securitisation' theory developed by the Copenhagen School, the discourse of security is understood as a 'speech act' in the processes of constructing a shared understanding of what is considered a threat. In such processes, the securitisation theory identifies 'referent objects' (which are seen to be existentially threatened) as distinguished from 'securitising actors' (who securitise issues) and 'functional actors' (who affect the dynamics of decision-making). See, B. Buzan, O. Wæver and J. de Wilde, Security: A New Framework for Analysis (Boulder: Lynne Rienner, 1998) 23-36.

${ }^{27}$ Peter Hough, Understanding Global Security (Routledge, 2004) 8-10. See also, Gary King and Christopher J L Murray, 'Rethinking Human Security' (2001) 116 Political Science Quarterly 585, 592-597; David T Graham and Nana Poku, Migration, Globalisation and Human Security (Routledge 2000) 17 .

${ }^{28}$ Barry Buzan, 'A Reductionist, Idealistic Notion that Adds Little Analytical Value' (2004) 35 Security Dialogue 369-370.
} 
addresses a wider range of causes of insecurity as part of security policy agendas. ${ }^{29}$ Furthermore, various human security threats are mutually reinforcing and interconnected because of their causal effect - for example, violent conflicts can lead to reduction in food production and poverty, or vice versa - often spreading across national borders into a wider region. ${ }^{30}$ Yet, such a potentially unlimited conception of human security has been criticised as being too ambiguous to be of any use for policymaking ${ }^{31}$ in that 'virtually any kind of unexpected or irregular discomfort could conceivably constitute a threat to one's human security'. ${ }^{32}$

In response to such criticism, a much narrower, minimalist conception of human security has emerged, placing human security squarely within the context of violence and conflict; such as the protection of civilians, women and children in armed conflict. ${ }^{33}$ It was this narrow conception of human security which provided a theoretical foundation for the development of the 'responsibility to protect' concept and the associated debate on military intervention to protect civilian populations from mass atrocities. ${ }^{34}$ However, this narrow conception of human security has also been subjected to criticism for prioritising the values favoured by the Global North over those held in the Global South. ${ }^{35}$

Third, unlike traditional, state-centred security which is often concerned with threats of armed attack, human security is to be achieved in a multidimensional and comprehensive manner. Thus, the Commission on Human Rights emphasises both protection and empowerment in an integrated approach to address a range of insecurities. ${ }^{36}$ It incorporates the idea of human development pioneered by Mahbub ul Haq, which has helped shift the focus of development issues from economic growth to the quality and richness of human lives. ${ }^{37}$ The idea of empowerment also closely relates to emancipation. As Ken Booth observes:

'Security' means the absence of threats. Emancipation is the freeing of people (as individuals and groups) from those physical and human constraints which stop them carrying out what they would freely choose to do. War and the threat of war is one of those constraints, together with poverty, poor education, political oppression and so on.

\footnotetext{
${ }^{29}$ Commission on Human Security (n 1); Tadjbakhsh and Chenoy (n 1) 29-30; MacFarlane and Khong (n 1$) \operatorname{ch} 4$.

${ }^{30}$ UNDP (n 3) 22-23; UN Human Security Unit, Human Security in Theory and Practice: Application of the Human Security Concept and the United Nations Trust Fund for Human Security (New York: United Nations, 2009) 7-8; Tadjbakhsh and Chenoy (n 1) 16-17.

${ }^{31}$ Andrew Mack, 'A Signifier of Shared Values' (2004) 35(3) Security Dialogue 366, 367; Keith Krause, 'The Key to a Powerful Agenda, If Properly Delimited' (2004) 35(3) Security Dialogue 367368; S Neil MacFarlane, 'A Useful Concept that Risks Losing Its Political Salience' (2004) 35(3) Security Dialogue 368-369.

${ }^{32}$ Roland Paris, 'Human Security: Paradigm Shift or Hot Air?' (2001) 26(2) International Security 87102 , at 89.

${ }^{33}$ See, eg, Tadjbakhsh and Chenoy (n 1) 30-31; MacFarlane and Khong (n 1) ch 5; Human Security Centre, Human Security Report 2005: War and Peace in the 21st Century (OUP 2005) viii.

${ }^{34}$ International Commission on Intervention and State Responsibility, The Responsibility to Protect (International Development Research Centre, 2001) 15; Gareth Evans, The Responsibility to Protect: Ending Mass Atrocity Crimes Once and For All (Brookings Institution, 2008) 34-35.

${ }^{35}$ Tadjbakhsh and Chenoy (n 1) 35-36. Yuen Foong Khong, 'Human Security: A Shotgun Approach to Alleviating Human Misery?' (2001) 7 Global Governance 231-236. Cf. Mark Duffield, Global Governance and the New Wars: The Merger of Development and Security (Zed Books, 2005) 31-34.

${ }^{36}$ Commission on Human Security (n 1) 10-12.

${ }^{37}$ Commission on Human Security (n 1) 8.
} 
Security and emancipation are two sides of the same coin. Emancipation, not power or order, produces true security. Emancipation, theoretically, is security. ${ }^{38}$

Thus, progressive advocates consider that human security represents a transformation away from the traditional idea of security being provided by the sovereign state, to the protection and empowerment of the individual and the promotion of social progress through the merging of development and security. ${ }^{39}$ However, when translated into practice, human security tends to take the form of government foreign aid programs, as has been the case with Japan's development aid, ${ }^{40}$ in particular the UN Trust Fund for Human Security they created. ${ }^{41}$

Additionally, much narrower, but more distinct approaches to promoting human security have been considered. The 'rights-based' approach to human security, for example, attempts to explain that human rights underpin the normative and conceptual foundation of human security and serve as the means of ensuring human security. ${ }^{42}$ Another perspective is the state-based approach, as represented by the 'responsibility to protect' concept, which seeks out ways in which sovereign states can address security threats to human beings, rather than threats to their own national security or their international relations. ${ }^{43}$ However, due to the controversies over its precise focus and scope, there is a risk of human security being misused or misguiding the debate when such familiar ideas and existing legal frameworks are relied upon as the means of addressing human security concerns (as will be discussed in Section 5-2 as the pathology of human security). At least one of the reasons why human security has been widely advocated and received into policy agendas worldwide is the very recognition that existing ideas and legal frameworks do not sufficiently address contemporary security threats from the viewpoint of human beings. ${ }^{44}$ Any discussion about the means to address human security issues must begin by critically assessing the adequacy of existing ideas and legal frameworks.

Within the analytical framework of security, human security serves as a catalyst for expanding the horizon of contemporary security debates. The question relevant to this chapter is to what extent the idea of human security has or has not informed the development of international law, challenging its sovereignty-based structure. The remainder of this chapter examines this question in three different dimensions comprising the analytical framework of security, namely: (1) the focus (referent object) of security; (2) the scope of security issues; and (3) the means by which security threats are addressed.

\footnotetext{
${ }^{38}$ Ken Booth, 'Security and Emancipation' (1991) 17 Review of International Studies 313-326, at 319.

${ }^{39}$ Tara McCormack, 'Human Security and the Separation of Security and Development' (2011) 11(2) Conflict, Security \& Development 235-260, at 241.

${ }^{40}$ For details, see, eg, Makoto Sato, 'Human Security and Japanese Diplomacy: Debates on the Role of Human Security in Japanese Policy' in Giorgio Shani, Makoto Sato, and Mustapha Kamal Pasha (eds), Protecting Human Security in a Post 9/11 World: Critical and Global Insights (Palgrave Macmillan, 2007) 83-96.

${ }^{41}$ For details, see, eg, Oscar A Gómez S, 'What Is a Human Security Project? The Experience of the UN Trust Fund for Human Security' (2012) 24 Global Change, Peace \& Security 385-403.

${ }^{42}$ See, eg, Fen Osler Hampson, Madness in the Multitude: Human Security and World Disorder (OUP 2002), 16-23; Bertrand G Ramcharan, Human Rights and Human Security (Martinus Nijhoff 2002) 310.

${ }^{43}$ See, eg, Report of the Secretary-General (2010) (n 7) paras.20-22.

44 Thus, von Tigerstrom describes the basic functions of human security as 'agenda-setting', 'questionframing' and 'critiquing existing approaches': von Tigerstrom (n 12) 45-49. See also, O’Brien (n11) 2.
} 


\section{Shifting the Focus}

Even though human security is first and foremost designed to shift the focus or referent object of security away from the state to the individual, the idea of a humancentred approach itself is not alien to international law. ${ }^{45}$ International law, while being built upon the traditional, inter-state paradigm, has developed to accommodate a human-centred approach by incorporating, for example, the principle of equality and non-discrimination, the principle of respect for human dignity, and the principle of humanity. ${ }^{46}$ These principles have underpinned the development of international human rights law, refugee law, and international humanitarian law; particularly in the second half of the twentieth century. If human security could only provide a shift towards a more human-centred approach, it would not offer much value to the development of international law.

What distinguishes human security from the human-centric approach to international law, particularly international human rights law, is its place within the analytical framework of security. The human-centred approach to international law, as traditionally conceived, does not necessarily address the interests of human beings within the paradigm of security. Human security can even be considered a sub-set of the human-centred approach to international law, which has only recently evolved within the overall trend of expanding the concept of security in international policy discourses. Conceived as such, human security is inherently a public concept concerned with the security of individuals as members of the community, rather than each individual's own personal security. ${ }^{47}$ The manifestation of the human-centred approach to international law in the paradigm of security, through the form of human security, has challenged the traditional conception of security as the sovereign prerogative of states.

It is for this reason that the adoption of the 1997 Ottawa Treaty, ${ }^{48}$ the 1998 Rome Statute, ${ }^{49}$ and the 2000 Optional Protocol to the Convention on the Rights of the Child, ${ }^{50}$ amongst the body of human rights treaties, has been seen as legal development motivated and facilitated by embracing and prioritising human security over national security. Security concerns of human beings have essentially pushed international standards of behaviour into the areas which were traditionally considered

\footnotetext{
${ }^{45}$ See, von Tigerstrom (n 12) ch 3.

${ }^{46}$ Accordance with International Law of the Unilateral Declaration of Independence in respect of Kosovo (Advisory Opinion) [2010] ICJ Rep 403, 596-607 (Judge Trindade separate opinion). See more generally, Antônio Augusto Cançado Trindade, International Law for Humankind: Towards a New 'Jus Gentinum' (Martinun Nijhoff 2010); Theodor Meron, The Humanization of International Law (Martinus Nijhoff 2006).

${ }^{47}$ See also, Kaldor (n 1) 191; Makoto Sato, 'Human Security and Japanese Diplomacy: Debates on the Role of Human Security in Japanese Policy' in Giorgio Shani, Makoto Sato and Mustapha Kamal Pasha (eds), Protectig Human Security in a Post 9/11 World (Palgrave Macmillan 2007) 83-96, 92.

${ }^{48}$ Convention on the Prohibition of the Use, Stockpiling, Production and Transfer of Anti-Personnel Mines and on Their Destruction (adopted 18 September 1997, entered infor force 1 March 1999) 2056 UNTS 211.

${ }^{49}$ Rome Statute of the International Criminal Court (adopted 17 July 1998, entered into force 1 July 2002) 2187 UNTS 90.

${ }^{50}$ Optional Protocol to the Convention on the Rights of the Child on the Involvement of Children in Armed Conflicts (adopted 25 May 2000, entered into force 12 February 2002) 2173 UNTS 222.
} 
domestic concerns of states. ${ }^{51}$ Additionally, a more progressive view has been expressed, elevating the potential of human security into a norm that requires proportionality assessment under international humanitarian law to demonstrate that the legitimate military objective cannot be achieved by other means, rather than simply consider that civilian casualty is not excessive in relation to the concrete and direct military advantage anticipated. ${ }^{52}$ According to this progressive view, human security is considered a normative, additional factor to be taken into account in balancing between military necessity and humanitarian concerns, whilst different from human rights-based approach in that it does not suggest an obligation to avoid or minimise any risk to civilians. ${ }^{53}$ Thus, human security plays a much broader function than human rights by contributing to the development and re-interpretation of legal rules, but is at the same time narrower than human rights in that it is concerned with the 'security' of human beings, their survival, livelihood and dignity. ${ }^{54}$

Although the adoption of a new treaty or re-interpretation of existing legal rules may have been influenced and motivated by the idea of human security, whether this truly addresses human security concerns held by individuals is a different matter. States' approach to human security issues may well be selective and deal only with what states consider to be a threat to human beings, rather than what individuals perceive to be a threat to themselves. Furthermore, human security issues may well be addressed only in the way that states consider appropriate, rather than the way in which individuals themselves require them to be addressed. Illustrative of this point are the issues of internal displacement and protracted refugee situation (where the displaced people are often encamped on border areas for a prolonged period of time), which illuminate the inadequacy of the state-oriented, monolithic understanding of 'refugee protection' without having regard to the dynamics and complexity of specific situations and individuals under the existing international refugee law. ${ }^{55}$ There remains scope for revisiting even human-centred rules of international law so as to better accommodate the particular needs and circumstances of those who are suffering or perceiving threats.

\section{Expanding Security Agendas}

\footnotetext{
${ }^{51}$ See, eg, Rob McRae, 'Human Security in a Globalised World' in Rob McRae and Don Hubert (eds), Human Security and the New Diplomacy: Protecting People, Promoting Peace (McGill-Queen's University Press 2001) 14-27, at 25; Richard A Matthew, 'Human Security and the Mine Ban Movement I: Introduction', in Richard A Matthew, Bryan McDoland and Kenneth R Rtherford (eds), Landmines and Human Security: International Politics and War's Hidden Legacy (State University of New York Press 2004) 3-19

52 Tom Farer, 'Human Security: Defining the Elephant and Imagining Its Tasks' (2010) 1 Asian Journal of International Law 1-13, at 8. See also, Kaldor (n 1) 186.

${ }^{53}$ For discussion, see, eg, Kenneth Watkin, 'Assessing Proportionality: Moral Complexity and Legal Rules' (2005) 8 Yearbook of International Humanitarian Law 3, 34-41.

${ }^{54}$ See also, von Tigerstrom (n 12) 42.

${ }^{55}$ See, eg, Akiko Okudaira and Hitoshi Nasu, 'Revisiting the Concept of Protection in International Refugee Law: Implications of the Protracted Refugee Situation on the Thai-Myanmar Border' in Angus Francis and Rowena Maguire (eds), Protection of Refugees and Displaced Persons in the Asia Pacific Region (Ashgate 2013) forthcoming; Alice Edwards, 'Human Security and the Rights of Refugees: Trascending Territorial and Disciplinary Borders' (2009) 30 Michican Journal of International Law 763-807, 805; T A Aleinikoff, 'State Centered Refugee Law: From Resettlement to Containment' (1992) 14 Michigan Journal of International Law 120-138.
} 
Despite the conceptual debate concerning its scope as outlined above, there is no denying that human security has provided a theoretical foundation for expanding the range of security issues to be addressed, at least as policy agendas, including economic security, food security, health security and environmental security. ${ }^{56}$ The human security optic makes a significant contribution to how we consider the wider range of security issues in that it enables a consideration of the root causes of such issues - which are usually observed and felt at the local or regional level - from the perspective of those who are actually suffering or perceiving the threats, irrespective of their causal relationship with an armed conflict, which the state-centred notion of security has been primarily concerned about. Thus, human security is not simply a security multiplier, but demands the incorporation of 'non-traditional' security agendas, which pose challenges to the survival and well-being of peoples arising from non-military sources, ${ }^{57}$ as perceived by those who are suffering from the original causes, rather than as their consequences for armed conflict.

However, accommodating 'non-traditional' security agendas from a human security perspective within the existing framework of international law is not straightforward. The basic premise of international law inevitably poses a structural obstacle to 'mainstreaming' human security within the existing framework of international law. ${ }^{58}$ International law is a system of law based on the consent of sovereign states and hence does not allow much scope for accommodating non-state entities and individuals as subjects of international law. ${ }^{59}$ This structural obstacle of international law inhibits the full potential of human security being harnessed to address "nontraditional' security issues.

An example illustrating this problem is the issue of food security. The idea of food security has evolved over the last four decades from 'food supply security' focusing solely upon the availability of food supply as a security concern, ${ }^{60}$ to a more comprehensive concept of "physical and economic access to sufficient, safe and nutritious food'. ${ }^{61}$ It is the concept of human security that arguably facilitated this shift, as the 1994 UNDP Human Development Report expressly provides that food security "requires not just enough food to go around... [but] requires that people have ready access to food - that they have an "entitlement" to food, by growing it for themselves, by buying it, or by taking advantage of a public food distribution system'. ${ }^{62}$ This statement was made ahead of the 1996 World Food Summit where states, for the first time, embraced this wider understanding of food security. ${ }^{63}$

\footnotetext{
${ }^{56}$ UNDP (n 3) 24-30.

57 See generally, eg, Mely Caballero-Anthony, Ralf Emmers and Amitav Acharya (eds), NonTraditional Security in Asia: Dilemmas in Securitisation (Ashgate, 2006).

${ }^{58}$ Cf. Wolfgang Benedek, Matthias C Kettemann and Markus Möstl (eds), Mainstreaming Human Security in Peace Operations and Crisis Management: Policies, Problems, Potential (Routledge, 2011). ${ }^{59}$ Andrew Clapham, 'The Role of the Individual in International Law' (2010) 21 European Journal of International Law 25-30. Cf Claudio Grossman and Daniel D Bradlow, 'Are We Being Propelled Towards a People-Centered Transnatinoal Legal Order?' (1993) 9 American University Journal of International Law and Policy 1-25.

${ }^{60}$ Report of the World Food Conference, Rome, 5-16 November 1974 (United Nations, 1975) 9.

${ }^{61}$ Rome Declaration on World Food Security, adopted 13 November 1996, para.1, available at: http://www.fao.org/docrep/003/w3613e/w3613e00.htm (last accessed 22 May 2013).

${ }^{62}$ UNDP (n 3) 27.

${ }^{63}$ Rome Declaration on World Food Security (n 60).
} 
Nevertheless, the international trade rules,${ }^{64}$ including those intended to address food security issues, ${ }^{65}$ have remained as the legal and structural barriers to the adoption of flexible food security policies by individual countries. ${ }^{66}$ This is also despite the fact that the 2001 Doha Ministerial Declaration acknowledged that a range of non-trade concerns such as food security should be taken into account. ${ }^{67}$ This 'trade-centric' approach to human security is also evident in the trade protection of intellectual properties, which has been criticised as denying traditional farmers' accessibility of plant genetic resources for food and agriculture. ${ }^{68}$

The expansion of the security concept through the optic of human security has also influenced the mandate and activities of the UN Security Council, which appears to be the most appropriate forum to incorporate the trend, given that it has the primary responsibility for the maintenance of international peace and security within the UN system. Yet, it is a state-centric, military-oriented conception of security which underpins the UN collective security system, whose constitutive and legitimising aim has traditionally been the absence of armed aggression. ${ }^{69}$ Mainstreaming human security to address non-traditional security issue within its framework requires transformation of its normative and institutional foundations into those that adopt human security as the driving force in the search for substantive legitimacy based on universal values. ${ }^{70}$

As this author has discussed elsewhere, whilst the incorporation of a civilian protection mandate into peacekeeping operations has gone some way towards this direction, the prevailing view remains that non-traditional security issues such as health security, food security and climate change, are relevant to the UN Security Council only to the extent that those matters relate to conflicts. ${ }^{71}$ Thus, at least as it currently stands, the idea of human security has not been fully harnessed into collective security decision-making. It therefore remains to be seen whether and to

\footnotetext{
${ }^{64}$ The modern international trade law can arguably be conceived of as aiming to fulfil human security objectives with reference to improvement of living standards for all people and sustainable development: Robert Howse and Makau Mutua, Protecting Human Rights in a Global Economy: Challenges for the World Trade Organization (International Centre for Human Rights and Democratic Development 2000) 4.

${ }^{65}$ See especially, Agreement on Agriculture (adopted 15 April 1994, entered into force 1 January 1995) 1867 UNTS 410.

${ }^{66}$ For details, see, eg, Anagha Joshi, 'Food Security in the Great Lakes Region: Reconciling Trade Liberalisation with Human Security Goals' in Rosemary Gail Rayfuse and Nicole Veisfelt (eds), The Challenge of Food Security: International Policy and Regulatory Frameworks (Cheltenham: Edward Elgar, 2012) 44, 53-56; Carmen Gonzalez, 'Institutionslizing Inequality: The WTO, Agriculture and Developing Countries' (2002) 27 Columbia Journal of Transnational Law 431-487, at 476-481; Melaku Geboye Desta, 'Food Security and International Trade Law: An Appraisal of the World Trade Organization Approach' (2001) 35 Journal of World Trade 449-468.

67 WTO Doha Ministerial Declaration, adopted 14 November 2001, Doc WT/MIN(01)/DEC/1, paras.13-14.

68 'Report of the Special Rapporteur on the Right to Food', UN Doc A/64/170, 23 July 2009, para.10. See generally, Robin Ramcharan, International Intellectural Property Law and Human Security (The Hague: TMC Asser, 2013).

${ }^{69}$ See, eg, Mariano-Florentino Cuéllar, 'Reflections on Sovereignty and Collective Security' (2004) 40 Stanford Journal of International Law 211-257, at 215-220; Hilary Charlesworth, 'The Inadequacy of "Collective Security"” (2000) 9 Finnish Yearbook of International Law 39-46, at 41-44.

${ }^{70}$ Hitoshi Nasu, 'Operationalising the "Responsibility to Protect" and Conflict Prevention: Dilemmas of Civilian Protection in Armed Conflict' (2009) 14 Journal of Conflict \& Security Law 209, 232-233.

${ }^{71} \mathrm{Nasu}$ (n 12).
} 
what extent the legal and political structure of the UN collective security system is capable of accommodating human security perspectives in dealing with both traditional and non-traditional security issues. The answer to this question may well depend on whether and how the multi-sectoral approach required to realise human security can be integrated into collective security actions, which forms the subject of the next section.

\section{Roles of Human Security in International Law}

\section{5-1. Multidimensional Approach to Security}

The concept of human security functions as a goal as much as the means to achieve the goal. As the 1994 Human Development Report sets out, it promotes not only the 'protection' of human beings but also the 'empowerment' of people to develop their potential, through concerted efforts to develop norms, processes and institutions that systematically address insecurities. The UN Secretary-General Ban Ki-Moon in his 2010 Human Rights Report also considers that the concept of human security introduces a practical framework for identifying specific insecurities as well as for considering the institutional and governance arrangements that are needed to ensure the survival, livelihood and dignity of individuals and communities in a multidimensional and comprehensive manner. ${ }^{72}$ Conceived as such, the role of human security as a security multiplier also extends the means by which security threats are to be addressed.

Nevertheless, the prevalent position among states remains that human security is to be achieved within the existing framework of international law and therefore does not entail new legal obligations for states, effectively rejecting any shift away from the traditional idea of security being provided by the sovereign state. ${ }^{73}$ Within the European Union, it is considered that '[r]espect for all human rights and the rule of law should remain at the core of any application of the human security approach'. ${ }^{74}$ Although the concept of human security itself may not create any new legal obligations, it does not mean that human security is devoid of any legal and normative values. Indeed, as the Australian delegation to the UN General Assembly observed, human security provides a 'normative framework' to ensure that our collective actions are not fragmented and that they directly benefit affected populations. ${ }^{75}$

It is in this normative context that mainstreaming human security can make a contribution in developing or re-conceptualising rules of international law. As examined above, human security has motivated and influenced the adoption of new treaties, so far mainly in the area of arms control, ${ }^{76}$ which could and should expand into other areas such as the international trade law regime. ${ }^{77}$ The notion of human security could also allow international and regional courts and tribunals to expand

\footnotetext{
${ }^{72}$ Report of the Secretary-General (2010) (n 7) para.26.

${ }^{73}$ UN Doc A/66/PV.112 (4 June 2012) 6 (Egypt), 7 (Cuba, Mexico), 8 (Venezuela), 12 (Russia), 15 (India), 19-20 (Syria). See also, Report of the Secretary-General (2012) (n 7) para.36(c).

${ }^{74}$ UN Doc A/66/PV.112 (4 June 2012) 3.

${ }^{75}$ UN Doc A/66/PV.112 (4 June 2012) 10 (Australia).

${ }^{76}$ See above $\mathrm{n}$ and accompanying text.

${ }^{77}$ Note the legal and structural obstracles to the adoption of flexible food security policies under the current WTO regime, as introduced above $\mathrm{n}$ and accompanying text.
} 
their approach to security. Judge Koroma, for example, in considering the request for the indication of provisional measures in Armed Activities on the Territory of the Congo, held in his Declaration that the Court's role in maintaining international peace and security includes the promotion and protection of human security and the right to life, having regard to the real and serious threats that existed to the population of the region concerned. ${ }^{78}$ In the Kosovo advisory opinion, Judge Trindade relied upon human security in observing that states have the "duty to protect and to empower their inhabitants' (emphasis original). ${ }^{79}$

Such a positive obligation upon states has been recognised in the context of the right to security through international, regional and domestic human rights jurisprudence. ${ }^{80}$ A reading of human security into the positive obligation of states to protect their inhabitants from violence and to empower, however, raises concern for the tension between liberty as an individual right and security (including human security) as a public or collective interest. ${ }^{81}$ Should human security be incorporated into the right to security so as to re-conceptualise or expand the right, the question inevitably arises as to how the potential conflict between the right to security (for example, of the public from terrorist threats) and other human rights such as the right to liberty and fair trial (for example, of suspected terrorists) should be reconciled. ${ }^{82}$ Some may argue that the right to security is superior to other human rights, ${ }^{83}$ whereas others consider that the right to security should be narrowly confined to avoid such conflict. ${ }^{84}$ Indeed, as will be discussed below, a certain application of a human security perspective leads to a pathological debate on the use of human security as a justification for controversial measures within the existing legal framework.

\section{5-2. Pathology of Human Security}

While human security is, as argued above, essentially a public concept concerned with the security of individuals as members of the community, rather than each individual's own personal security, too much emphasis on the collective as opposed to each individual blurs the line between human security and national security. In a twisted sense, human security can be conceived of as a necessary precondition to the society in which human rights can be exercised, and thus justify derogation from the human rights of certain individuals. This is the line of argument that the former Canadian Attorney-General Irwin Cotler adopted in assessing the human rights compatibility of controversial counter-terrorism legislation by describing it as

\footnotetext{
78 Case Concerning Armed Activities on the Territory of the Congo (New Application: 2002) (Democratic Republic of the Congo v Rwanda) (Provisional Measures) [2002] ICJ Reports 219, 253254.

${ }^{79}$ Accordance with International Law of the Unilateral Declaration of Independence in respect of Kosovo (Advisory Opinion) [2010] ICJ Reports 403, 594 (Judge Trindade Separate Opinion).

${ }^{80}$ See, eg, James Spigelman AC, 'The Forgotten Freedom: Freedom from Fear' (2010) 59 International and Comprative Law Quarterly 543, 549-559; Sandra Fredman, 'The Positive Right to Security' in Benamin J Goold and Liora Lazarus (eds), Security and Human Rights (Hart Publishing, 2007) 307-324; Liora Lazarus, 'Mapping the Right to Security' in Benamin J Goold and Liora Lazarus (eds), Security and Human Rights (Hart Publishing, 2007) 325-345.

${ }^{81}$ Spigellman (n 79) 549.

${ }^{82}$ For discussion, see, eg, Piet Hein van Kempen, 'Four Concepts of Security - A Human Rights Perspective' (2013) 13 Human Rights Law Review 1-23.

${ }^{83}$ Cf Jeremy Waldron, 'Security and Liberty: The Image of Balance' (2003) 11 Journal of Political Philosophy 191-210, at 208-209.

${ }^{84}$ See, eg, Lazarus (n 79) 344.
} 
"'human security" legislation that purports to protect both national security and civil liberties'. 85

A similar position was adopted by the former Australian Attorney-General Philip Ruddock in his theoretical, human security-based rationale for Australia's controversial counter-terrorism legislation. According to Ruddock:

Human security is a broad concept focused on the individual or community, rather than the state. Human security rests upon security for the individual citizen, which requires not only the absence of violent conflict, but also respect for human rights and fundamental freedoms...

While it is accepted that any tightening of security arrangemnets will impact on certain rights, a more useful debate is to consider whether tightening security arrangements is in the interests of protecting fundamental human rights as a whole. ${ }^{86}$

This argument was advanced in justifying controversial counter-terrorism legislation that derogates from fundamental rights and freedoms in the process on the grounds that ultimately it promotes human security by preserving a society in which rights and freedoms can be exercised. What we see in this line of argument is reliance on the normative goal of human security as a way of shifting the balance between national security and individual human rights without explaining why the shift is towards the reduction of human rights (not the other way) or to what extent it can be shifted. ${ }^{87}$ The notion of human security is only given a limited consideration as a normative goal, without being projected into the third analytical security dimension concerning the means by which security threats are to be addressed. Human security is not a language of oppression, but rather one of empowerment and emancipation.

Another area that illustrates the potential pathological use of human security concerns the debate on humanitarian intervention. In particular, early literature on human security considers human security to be 'interventionist by nature' encompassing the use of force for more cosmopolitan goals. ${ }^{88}$ This, again, reflects the pitfall of a limited understanding of human security as only a 'normative goal' and the failure to harness its potential in full as the 'means' to address security threats. It would be too much to expect the human security approach to have positive impacts on the future debate about humanitarian intervention, given the inherent dilemma posed by competing

\footnotetext{
${ }^{85}$ Irwin Cotler, 'Thinking Outside the Box: Foundational Principles for a Counter-Terrorism Law and Policy' in Ronald J Daniels, Patrick Maklem and Kent Roach (eds), The Security of Freedom: Essays on Canada's Anti-Terroism Bill (University of Tronto Press, 2001) 111-129, at 112.

${ }^{86}$ Philip Ruddock, 'A New Framework: Counter-Terrorism and the Rule of Law' (2004) 16 The Sydney Papers 113-121, at 116-117.

${ }^{87}$ See, Ben Golder and Goerge Williams, 'Balancing National Security and Human Rights: Assessing the Legal Response of Common Law Nations to the Threat of Terrorism' (2006) 8 Journal of Comparative Policy Analysis 43-62, at 53.

${ }^{88}$ Gerd Oberleitner, 'Human Security: A Challenge to International Law?' (2005) 11 Global Governance 185-203, 194. See also, Kaldor (n 1) 182-197; Nicholas Thomas \& William T Tow, 'The Utility of Human Security: Sovereignty and Humanitarian Intervention' (2002) 33(2) Security Dialogue 177-192. Cf Priyankar Upadhyaya, 'Human Security, Humanitarian Intervention, and Third World Concerns' (2004) 33 Denver Journal of International Law and Policy 71-91.
} 
norms and moral imperatives, which cannot simply be resolved by embracing human security as a substitute for national security. ${ }^{89}$

Irrespective of the true intention behind the notion of human security, lingering concerns over the concept have been associated with suspicion that it might be used to justify unwarranted intervention in vulnerable countries for political reasons without having regard to the real needs and priorities of their peoples and even perhaps at the expense of their social and political stability. ${ }^{90}$ Policy-makers in Southeast Asia, for example, have been wary of the 'freedom from fear' aspect of human security, due to their apprehension that it may justify external intervention in their internal situations which often involve violations of human rights and international humanitarian law. ${ }^{91}$ The UN Secretary-General's follow-up report on human security and the following debate in the UN General Assembly in 2012 hit the nail on the coffin for the idea of linking human security with military intervention. This emphasised a common understanding that human security does not entail the threat or use of force and is implemented with full respect for the purposes and principles of the UN Charter including the full respect for state sovereignty and the principle of non-intervention. ${ }^{92}$ Moreoever, human security is now clearly distinguished and even dissociated from its sibling, the 'responsibility to protect' doctrine, ${ }^{93}$ presumably due to the political stigma attached to the latter in the aftermath of the NATO's intervention in Libya in March 2011 in the implementation of the doctrine under Security Council Resolution 1973. ${ }^{94}$

Nevertheless, concern for the misuse or abuse of human security for political interests of powerful states remains strong. Indeed, the persistent call for reaching an agreement on the definition of human security, expressed by a few states during the UN General Assembly debate on human security in 2012, appears to stem from the fear that a vaguely framed concept could potentially be misused. ${ }^{95}$ However, as examined above, it is the limited understanding of human security, rather than the ambiguity of the concept itself, that invites the misuse or abuse of the concept. Harnessing the full potential of human security, rather than seeking to define it in square, appears to be a better way to address the concern.

\section{Conclusion}

Notwithstanding (or thanks to) its amorphous nature, human security functions as a security multiplier in all three dimensions of the analytical framework of security. It

\footnotetext{
${ }^{89}$ See especially, Simon Chesterman, Just War or Just Peace? Humanitarian Intervention and International Law (OUP) 2001; von Tigerstrom (n 12) ch 4. See also, David Chandler, 'Resilience and Human Security: The Post-Interventionlist Paradigm' (2012) 43(3) Security Dialogue 213-229.

${ }^{90}$ UN Doc A/66/PV.112 (4 June 2012), 6 (Egypt), 8 (Venezuela), 9 (Japan), 14 (Costa Rica), 15 (India), 21 (China).

${ }^{1}$ Yukiko Nishikawa, Human Security in Southeast Asia (Routledge 2010) 37; Amitav Acharya, Promoting Human Security: Ethical, Normative and Educational Frameworks in South-East Asia (UNESCO, 2007) 21.

${ }^{92}$ Report of the Secretary-General (2012) (n 7) para.36.

${ }^{93}$ Report of the Secretary-General (2012) (n 7) paras.22-23. See also, UN Doc A/66/PV.112 (4 June 2012) 6 (Egypt), 7 (Cuba), 9 (Japan), 12 (Russia), 15 (India), 16 (Brazil), 18 (Malaysia), 19 (Pakistan), 20 (Syria). Cf Report of the Secretary-General (2010) (n 7) paras.23-24.

${ }^{94}$ See, David Berman and Christopher Michaelson, 'Intervention in Libya: Another Nail in the Coffin for the Responsibility-to-Protect?' (2012) 14 International Community Law Review 337-358.

${ }^{95}$ See, eg, UN Doc A/66/112 (4 June 2012) 16 (Brazil), 19 (Syria).
} 
provides a normative and practical framework to ensure that concerted efforts to develop norms, processes and institutions systematically address insecurities from the perspective of those who are actually suffering or perceiving the threats. However, this chapter has demonstrated that its limited normative impact so far has been due to the restricted application of the notion, as much as the legal and structural obstacles within the existing framework of international law. Thus, the idea of human security challenges international law not only in respect of its sovereignty-based legal framework but more significantly in relation to the very notion of security shared by policy-makers and jurists.

By embracing and promoting the notion of human security to its full potential, existing obligations such as those towards refugees, internally displaced people and those who are in protracted refugee situations can be revisited in order to facilitate a more appropriate implementation that accommodates their perspective. ${ }^{96}$ It may also promote the adoption of new treaties, amendment or re-interpretation of existing treaty obligations in a broader range of areas such as food security, health security and climate change. The potential of human security's normative effects is yet to be fully harnessed. Therefore, it remains to be seen to what extent mainstreaming human security will actually challenge the sovereignty-based framework of international law and to what extent the legal and political structure of the UN collective security system is capable of accommodating human security perspectives in dealing with both traditional and non-traditional security issues.

Embracing and harnessing the full potential of human security is also important in order to prevent a misuse or abuse of the notion for promoting or attempting to justify traditional, oppressive means to achieve security under the guise of 'human security'. A practical framework provided by human security broadens the way in which we consider and address security issues - not simply through a rights-based approach or development aid, but also more importantly by recognising and promoting its contribution to new legal development and new jurisprudence. The normative and practical impacts of human security on the development of international law thus depend on the extent to which states, policy-makers and jurists are prepared to move beyond the definitional debate and embrace its perspective and philosophy of empowerment in their decision-making processes.

\footnotetext{
${ }^{96}$ Akiko Okudaira and Hitoshi Nasu, 'Revisiting the Concept of Protection in International Refugee Law: Implications of the Protracted Refugee Situation on the Thai-Myanmar Border' in Angus Francis and Rowena Maguire (eds), Protection of Refugees and Displaced Persons in the Asia Pacific Region (Ashgate, 2013) 171-183.
} 